\title{
Correction to: The impact of stochastic physics on the El Niño Southern Oscillation in the EC-Earth coupled model
}

\author{
Chunxue Yang ${ }^{1,5} \cdot$ Hannah M. Christensen ${ }^{2,3} \cdot$ Susanna Corti ${ }^{1} \cdot$ Jost von Hardenberg ${ }^{4} \cdot$ Paolo Davini $^{4}$
}

Published online: 7 May 2019

(c) The Author(s) 2019

\section{Correction to: Climate Dynamics}

https://doi.org/10.1007/s00382-019-04660-0

The article The impact of stochastic physics on the El Niño Southern Oscillation in the EC-Earth coupled model, written by Chunxue Yang, Hannah M. Christensen, Susanna Corti, Jost von Hardenberg and Paolo Davini, was originally published electronically on the publisher's internet portal (currently SpringerLink) on 07 February 2019 without open access.

With the author(s)' decision to opt for Open Choice the copyright of the article changed on 15 March 2019 to (c) The Author(s) 2019 and the article is forthwith distributed under the terms of the Creative Commons Attribution 4.0
International License (http://creativecommons.org/licenses/ by/4.0/), which permits use, duplication, adaptation, distribution and reproduction in any medium or format, as long as you give appropriate credit to the original author(s) and the source, provide a link to the Creative Commons license and indicate if changes were made.

Open Access This article is distributed under the terms of the Creative Commons Attribution 4.0 International License (http://creativecommons.org/licenses/by/4.0/), which permits unrestricted use, distribution, and reproduction in any medium, provided you give appropriate credit to the original author(s) and the source, provide a link to the Creative Commons license, and indicate if changes were made.

The original article can be found online at https://doi.org/10.1007/ s00382-019-04660-0.

Chunxue Yang

chunxue.yang@artov.isac.cnr.it

1 Istituto di Scienze dell'Atmosfera e del Clima, Consiglio Nazionale delle Ricerche (ISAC-CNR), Bologna, Italy

2 Atmospheric, Oceanic and Planetary Physics, University of Oxford, Oxford, UK

3 National Center for Atmospheric Research, Boulder, CO, USA

4 Istituto di Scienze dell'Atmosfera e del Clima, Consiglio Nazionale delle Ricerche (ISAC-CNR), Torino, Italy

5 Istituto di Scienze Marine, Consiglio Nazionale delle Ricerche (ISMAR-CNR), Via del Fosso del Cavaliere, 100, 00133 Rome, Italy 